\title{
En el III Centenario de Ruiz de Alarcón
}

Llamado a tomar parte en esta conmemoración, trayendo a ella la representación de los elementos españoles hoy agrupados, por iniciativa generosa del gobierno de la República Mexicana, en la Casa de España en México, yo quisiera traer asimismo una más amplia representación, ya que las circunstancias actuales me impiden ostentar la que me correspondería en mi calidad de miembro de la Academia Española de la Lengua. Esta entidad habría de aparecer asociada igualmente a los distintos actos con que se recuerda en su solar nativo a don Juan Ruiz de Alarcón y Mendoza en el tercer centenario de su muerte, ocurrida en Madrid y en tal día como hoy. La Academia, que se honró al tributar homenaje al autor de La verdad sospechosa consagrándole los tres primeros volúmenes de su "Biblioteca Selecta de Autores Españoles", dando en ellos una serie de sus obras dramáticas ilustradas con el comentario de don Patricio de la Escosura, y que editó además la vida de Alarcón escrita por don Luis Fernández-Guerra, libro que, aun superado hoy por la investigación erudita y la apreciación de los críticos, marca un punto de arranque en los estudios alarconianos, abre las puertas de su fachada neoclásica - no quiero olvidarlo, aunque parezca menudo pormenor, por íntimas razones que la enlazan a mis recuerdos familiares- precisamente a la 
calle de Alarcón, situada en uno de los lugares más bellos de Madrid, cercana al Buen Retiro y al Prado, jardines y paseos en que aún perdura el ambiente de nuestra comedia nacional. Yo la estimo, pues, en su integridad constitutiva, adherida a éste homenaje y a los demás con que ahora recuerda México a su genial dramaturgo, y a falta de mandato expreso me arrogo, para considerarla incorporada a mí, un título que ella me otorgó generosamente, con relación a mis escasos méritos. $\mathrm{Y}$ aun, a trueque de mostrar ambición desmedida, quisiera representar también a los españoles de México en general, a los que hoy desarrollan sus actividades en tierra mexicana, sin dejar de ser españoles, como un día, tres siglos ha, fué nuestro Alarcón -es decir, el Alarcón de vosotros y de nosotros- a buscar a sus pretensiones y aptitudes campo y lucimiento provechoso en España.

El nombre de Ruiz de Alarcón, que desde hoy aparece en uno de los más bellos lugares de México, es, para los españoles, como para los mexicanos, signo de íntima compenetración y prenda segura de colaboración estrecha. Cuando se haya demostrado que los rasgos fundamentales con que resplandece su obra son propios del genio mexicano y poco deben al lugar en que hubieron de lograrse $y$ desenvolverse, siempre quedará en pie la circunstancia aludida; y, lo que vale mucho más, siempre lucirá para España, como una pura faceta en el rico prisma de su teatro nacional, el espíritu de Alarcón, severo, adoctrinador, cargado de experiencia y de gracia, lleno de serenidad entre aquel tumulto apasionado y turbulento, adorador de lo heroico y también de lo grandilocuente, amigo de la sutileza y de la rusticidad a la vez, y no negado a la cortesanía y a la mesura que de tal modo destellan en las más logradas escenas del teatro de Alarcón, en quien esos aspectos asumen el papel de caracterización fundamental, mientras sólo consiguen asomar, en otros auttores, como virtudes accesorias.

Quizá deba mucho Alarcón, en los principios de un arte que cultivó preferentemente en España, a la sociedad y à la litera- 
tura en torno; pero es evidente, y esto es lo que hoy nos importa reconocer y proclamar ante todo, que aquella sociedad le debe algunas de sus lecciones más provechosas; que en su teatro, como en el más claro espejo, pudo contemplar algunas de sus virtudes más hondas, la lealtad a la palabra, la fidelidad sin ostentación, así como reconocer y corregir sus vicios, tanto los superficiales que hasta llegan a parecer simpáticos, si los encarna un personaje visto afectuosamente por el autor, como los más torvos y profundos, que él flagela y castiga con una severidad en que cuesta trabajo advertir la ira y el ceño.

Por estos motivos no es posibie considerar a España ausente en la conmemoración del gran poeta mexicano que encontró allá, es cierto, enemistades y burlas, pero ¿de quién?... De la grey literaria, de las gentes del oficio, de los posibles competidores y efectivos rivales, caracterizados siempre por lo agrio de las disputas, aun en los dioses mayores, y que lanzaron sus flechas contra un cuerpo deforme, dejando indemne la perfección moral y también corporal del teatro de Alarcón - que es manifestación palpable de lo que pudiera sintetizar el célebre dicho latino, mens sana in corpore sano, tanto en sus intenciones y dotes más hondas, como en la tersura de su construcción escénica y de su vestidura rimada. Enemistades y burlas que sólo quedan en episodios sin trascendencia verdadera, mientras que sería imposible escribir la historia del teatro hispano sin detenerse ante don Juan Ruiz de Alarcón, que tuvo de su parte al pueblo que le aplaudió y a la crítica que siempre ha sabido estimarlo.

Ojalá sea esta conmemoración para el teatro mexicano punto de partida de un nuevo florecimiento, en que logren constante vida escénica las obras del propio Alarcón y las de sus continuadores de todas las épocas, y se abra ancha liza para los nuevos escritores, a la altura, indudablemente, en lo que toca a la inspiración y al sentido teatral, de las más vivas corrientes universales, pero no favorecidas por una inmediata aproximación a un público al que podrían infiltrar sus ideales estéticos, y en 
el que, en cambio, habrian de hallar el necesario contraste, debiéndole sin duda, ya que no lecciones positivas, orientaciones de experiencia que harían un sólo cuerpo de autores, comediantes y espectadores, elementos los tres esenciales en toda próspera vida teatral.

Si a México le basta para tener un puesto glorioso en ia historia universal del teatro el ser patria de Alarcón, le importa también que su ejemplo no se pierda y que su memoria no se reduzca a solaz o fatiga de eruditos, a lápida vistosa en que se ostente el nombre de Alarcón en un lugar transitado. Recuérdese, ante todo, que así como una de las facetas gloriosas del teatro español, es uno de los exponentes inmortales del genio mexicano al que, unidos con vosotros los españoles, rendimos hoy tributo de admiración, del que apenas estas palabras mías habrán alcanzado a ser un reflejo pálido.

Enrigue Dífz-Canedo. 